УдК 663.098, 663.664

\title{
DEVELOPMENT OF STANDARDS FOR MAXIMUM ALLOWABLE ALCOHOL LOSSES IN THE PRODUCTION OF ALCOHOL-CONTAINING PRODUCTS FROM A MASH
}

\author{
G. Kyziun, O. Mishchenko, A. Моzharovsка \\ SSI «Ukrainian Research Institute for Alcohol and Biotechnology of Food Products» \\ S. Oliynyk \\ National University of Food Technologies
}

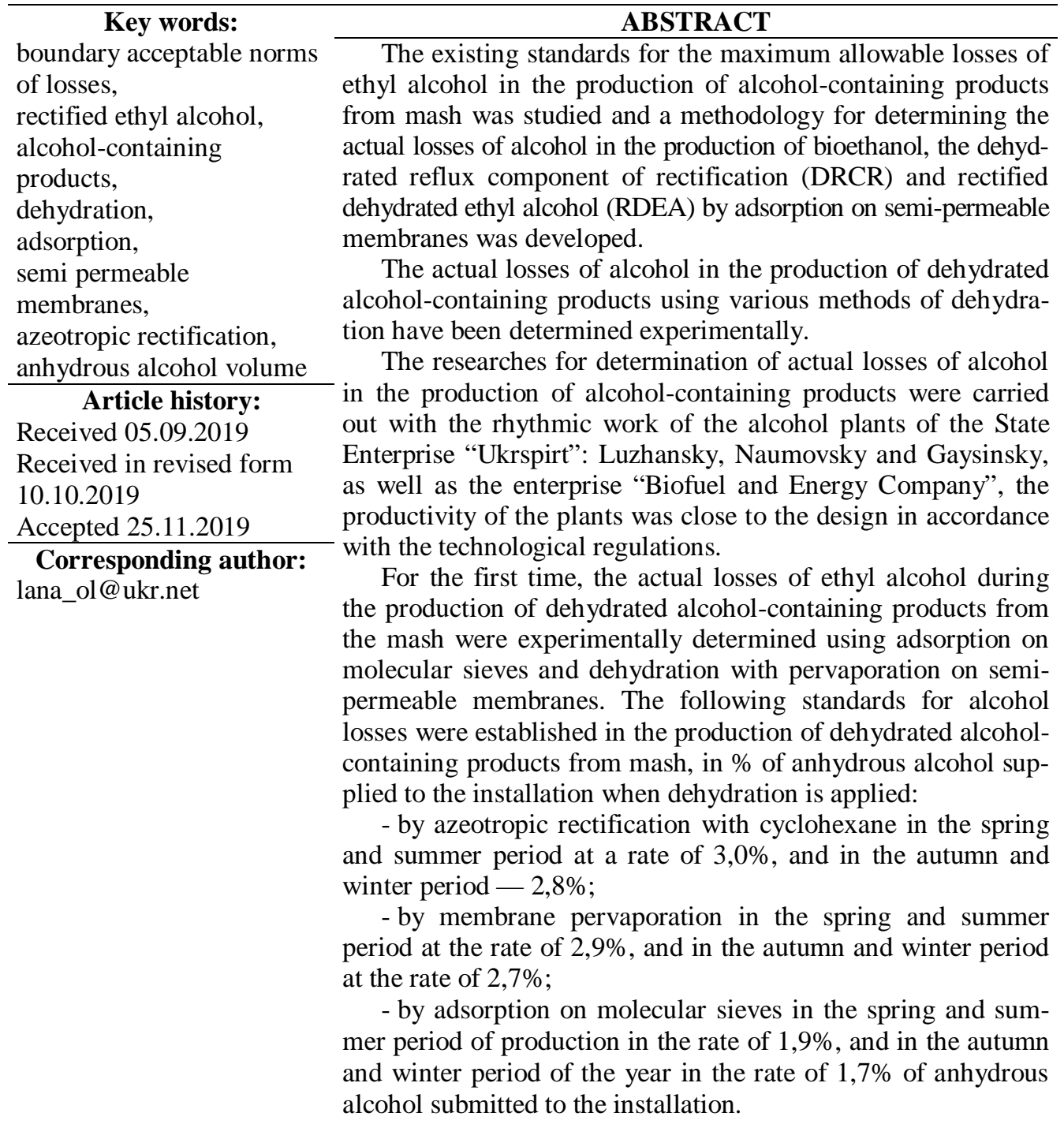

DOI: $10.24263 / 2225-2916-2019-26-5$

(C) Г. О. Кизюн, О. С. Міщенко, А. А. Можаровська, С. І. Олійник, 2019 


\title{
РОЗРОБЛЕННЯ НОРМАТИВІВ ГРАНИЧНО ДОПУСТИМИХ ВТРАТ СПИРТУ ЕТИЛОВОГО ПІД ЧАС ВИРОБНИЦТВА ЗНЕВОДНЕНОЇ СПИРТОВМІСНОЇ ПРОДУКЦІЇ З БРАЖКИ
}

\author{
Г. О. Кизюн, канд. техн. наук \\ О. С. Міщенко, канд. техн. наук \\ А. А. Можаровська \\ ДНУ «УкрНДІспиртбіопрод» \\ С. І. Олійник, канд. техн. наук \\ Національний університет харчових технологій
}

Проаналізовано існуючі нормативи гранично допустимих втрат спирту етилового під час виробництва спиртовмісних продуктів із бражки та розроблено методику визначення фрактичних втрат спирту під час виробництва біоетанолу, фрлегмового компонента ректифікації зневодненого (ФКРЗ) і спирту етилового ректифрікованого абсолютованого (СEPA) методом адсорбиії на напівпроникливих мембранах та азеотропною ректифікацією. Експериментальним иляхом визначено фрактичні втрати спирту у виробництві зневодненої спиртовмісної продукції при застосуванні різних способів зневоднення. Узагальнено результати досліджень і розроблено проект нормативів гранично допустимих втрат спирту під час виробництва спиртовмісної продукції з дозрілої бражки.

Ключові слова: гранично допустимі нормативи втрат, спирт етиловий ректифрікований, спиртовмісна продукція, зневоднення, адсорбція, напівпроникливі мембрани, азеотропна ректиорікація, об'єм безводного спирту.

Постанова проблеми. У виробництві спирту етилового ректифікованого та інших спиртовмісних рідин із бражки одним із основних показників, що підлягають контролюванню, $\epsilon$ величина втрат спирту етилового ректифікованого, яка не повинна перевищувати гранично допустимі значення, визначені нормативами допустимих втрат спирту, розробленими та затвердженими в установленому порядку [1].

У виробництві підприємства використовують нормативні втрати спирту, розроблені у 2005 р. та затверджені Департаментом 3 питань адміністрування акцизного збору i контролю за виробництвом та обігом підакцизних товарів ДПА України «Нормативи допустимих втрат спирту на безперервно діючих брагоректифікаційних установках» («Нормативи...»), які втратили свою чинність. Цими «Нормативами...» визначено гранично допустимі втрати спирту на безперервно діючих брагоректифікаційних установках під час виробництва спирту етилового ректифікованого різних сортів спирту етилового технічного марок А, Б і В та флегмового компонента ректифікації денатурованого. Крім того, визначено гранично допустимі втрати при виробництві зневоднених продуктів, зокрема спирту етилового ректифікованого абсолютованого, спирту етилового технічного марок Г, Д і Е, флегмового компонента ректифікації денатурованого зневодненого на установках зневоднення азеотропною ректифікацією.

Однак за час дії вказаних «Нормативів...» було освоєно виробництво ряду нових зневоднених спиртовмісних продуктів, перш за все біоетанолу, а також інших продуктів технічного призначення. Для їх випуску розроблено та впроваджено у виробництво ряд нових технологій, таких як зневоднення адсорбцією на молекулярних ситах i зневоднення за допомогою напівпроникливих мембран, які відрізняються від азеотропного зневоднення суттєво меншими енергетичними 
витратами. Для цих виробництв наразі взагалі відсутні науково обгрунтовані нормативи втрат спирту [2-5].

Метою досліджень $є$ встановлення фактичних втрат спирту етилового під час виробництва з бражки спиртовмісної продукції, в тому числі нових видів продукції та за новими технологіями.

Матеріали і методи. Визначення фактичних втрат спирту у виробництві спиртовмісної продукції здійснювали за ритмічної роботи підприємства, на якому проводили дослідження, з продуктивністю близькою до проектної продуктивності установки згідно з технологічним регламентом, за умови достатньої забезпеченості нагрівальною парою, водою для охолодження та кваліфікованим обслуговуючим персоналом згідно зі штатним розписом. Тривалість ритмічної роботи підприємства для успішного проведення досліджень становила 10-15 діб.

Окрім того, обов'язковими умовами для проведення досліджень були:

- наявність і справність запірної арматури, яка забезпечує можливість обліку кількості дозрілої бражки, що подають на перероблення на установку;

- наявність і справне функціонування АСУТП установки згідно з вимогами технологічного регламенту;

- наявність і справність системи обліку готової спиртовмісної продукції.

Експериментальні дослідження проводились на Лужанському МПД ДП «Укрспирт», ДП «Наумівський спиртовий завод», ДП «Гайсинський спиртовий завод» та підприємстві ТОВ «Біопаливно-енергетична компанія» (м. Луцьк).

Під час досліджень на Лужанському МПД ДП «Укрспирт» перероблялась бражка, одержана при зброджуванні меляси за двопотоковою схемою зброджування сусла підвищеної концентрації. Визначено фактичні втрати спирту під час виробництва флегмового компонента ректифікації зневодненого денатурованого (ФКРЗД) з бражки із застосуванням зневоднення азеотропною ректифікацією 3 циклогексаном у весняно-літній період року.

Під час досліджень на ДП «Наумівський спиртовий завод» переробляли бражку, одержану при зброджуванні меляси за двопотоковою схемою. Бражку переробляли на двох брагоректифікаційних установках (БРУ) непрямої дії. Визначено фактичні втрати спирту під час виробництва біоетанолу з бражки із застосуванням зневоднення методом мембранної первапорації у весняно-літній та осінньо-зимовий періоди.

Під час досліджень на ДП «Гайсинський спиртовий завод» переробляли бражку, одержану при переробці меляси за схемою періодичного зброджування. Визначено фактичні втрати спирту під час виробництва біоетанолу з бражки із застосуванням зневоднення адсорбцією на молекулярних ситах у весняно-літній період та осінньо-зимовий періоди.

Для встановлення «Нормативів...» було визначено середні втрати на кожному підприємстві для певної пори року у відсотках по відношенню до безводного спирту поданого на установку.

Результати досліджень систематизували із застосуванням математичних i статистичних методів та програмного забезпечення, також проведено обробку масиву даних.

Результати дослідження. Враховуючи, що адсорбція води на молекулярних ситах наразі $є$ найбільш розповсюдженим способом зневоднення, з метою уточнення фактичних втрат спирту було додатково проведено чотири досліди 3 визначення втрат спирту в осінньо-зимовий період року при виробництві з бражки зневодненого спиртовмісного розчинника на підприємстві ТОВ «Біопаливноенергетична компанія» (м. Луцьк). Результати експериментальних досліджень наведено у табл. $1-2$. 
Для Лужанського МПД ДП «Укрспирт» середні фактичні втрати спирту у весняно-літній період року при виробництві ФКРЗД з бражки із застосуванням зневоднення азеотропною ректифікацією за результатами трьох дослідів склали:

$$
B_{\text {cep. }}=(105,4+96,3+97,4) \cdot 100 /(3503,2+2999,7+3452,0)=3,0 \% \text {. }
$$

Середні фактичні втрати спирту під час виробництва біоетанолу з бражки із застосуванням зневоднення на напівпроникливих мембранах на ДП «Наумівський спиртовий завод» у весняно-літній період року склали:

$$
\mathrm{B}_{\text {cep. }}=(156,1+153,6+37,5) \cdot 100 /(5305,6+5397,2+1239,8)=2,91 \% \text {; }
$$

- в осінньо-зимовий період року:

$$
B_{\text {cep. }}=(131,1+74,7+72,8) \cdot 100 /(4886,7+2686,5+2737,6)=2,7 \% .
$$

Середні фактичні втрати спирту під час виробництва біоетанолу з бражки із застосуванням зневоднення адсорбцією на молекулярних ситах на ДП «Гайсинський спиртовий завод» у весняно-літній період року склали:

$B_{\text {cep. }}=(104,8+97,1+128,7+131,0) \cdot 100 /(5589,4+5553,2+6615,2+6810,1)=1,88 \%$;

- в осінньо-зимовий період року:

$$
B_{\text {cep. }}=(107,6+104,8+114,1) \cdot 100 /(6157,8+6632,5+6714,2)=1,67 \% .
$$

\begin{tabular}{|c|c|c|c|c|c|c|c|c|c|}
\hline \multirow{2}{*}{$\begin{array}{c}\text { Підприємство, } \\
\text { де проводили } \\
\text { дослідження } \\
\text { з визначення } \\
\text { фактичних } \\
\text { втрат спирту }\end{array}$} & \multirow[b]{2}{*}{$\begin{array}{l}\text { № } \\
\text { дос- } \\
\text { ліду }\end{array}$} & \multicolumn{2}{|c|}{$\begin{array}{c}\text { Кількість } \\
\text { безводного } \\
\text { спирту, дал }\end{array}$} & \multicolumn{4}{|c|}{$\begin{array}{c}\text { Фактичні втрати, дал } \\
\text { безводного спирту }\end{array}$} & \multicolumn{2}{|c|}{ Загальні втрати } \\
\hline & & $\begin{array}{c}\text { пода- } \\
\text { ного на } \\
\text { уста- } \\
\text { новку }\end{array}$ & $\begin{array}{c}\text { отри- } \\
\text { маного } 3 \\
\text { про- } \\
\text { дуктами }\end{array}$ & $\begin{array}{c}3 \text { бар- } \\
\text { дою }\end{array}$ & $\begin{array}{c}3 \\
\text { лютер- } \\
\text { ною } \\
\text { водою }\end{array}$ & $\begin{array}{c}3 \text { газа- } \\
\text { ми }\end{array}$ & \begin{tabular}{|c|} 
втрати, що \\
не визна- \\
чаються \\
експери- \\
ментально \\
\end{tabular} & \begin{tabular}{|c|} 
дал \\
безвод- \\
ного \\
спирту
\end{tabular} & $\begin{array}{c}\text { \% від } \\
\text { спирту } \\
\text { поданого } \\
\text { на уста- } \\
\text { новку }\end{array}$ \\
\hline Лужанське & 1 & 3503,2 & $\overline{3397, \varepsilon}$ & 4,7 & 0,8 & 4,8 & 95,1 & 105,4 & 3,00 \\
\hline МПД & 2 & 2999,7 & 2903,4 & 3,5 & 0 & 4,8 & 8 & 96 & 21 \\
\hline ДП «Укрспирт» & 3 & 3452,0 & 3354,6 & 4,4 & 0,8 & 5,6 & 86,6 & 97,4 & 2,82 \\
\hline ДП «Наумівсь- & 1 & 5305,6 & 5149,5 & 0,0 & 0,0 & 6,0 & 150,1 & 156,1 & 2,94 \\
\hline кий спиртовий & 2 & 5397,2 & 5243,6 & 9,7 & 0,0 & 9,3 & 134,6 & 153,6 & 2,85 \\
\hline завод» & 3 & 1239,8 & 1202,3 & 2,2 & 0,0 & 1,6 & 33,7 & 37,5 & 3,02 \\
\hline & 1 & 5589,4 & 5484,6 & 7,3 & 0,0 & 0,82 & 96,7 & 104,8 & 1,87 \\
\hline b- & 2 & 5553,2 & 5456,1 & 7,4 & 0,02 & 0,82 & 88,9 & 97,1 & 1,75 \\
\hline & 3 & 6615,2 & 6486,5 & 4,4 & 0,0 & 0,78 & 123,5 & 128,7 & 1,95 \\
\hline завод» & 4 & 6810,1 & 6679,1 & 7,4 & 0,04 & 0,81 & 122,8 & 131,0 & 1,92 \\
\hline
\end{tabular}

Таблиия 1. Фактичні втрати спирту етилового під час виробництва зневодненої спиртовмісної продукції з бражки у весняно-літній період

\begin{tabular}{|c|c|c|c|c|c|c|c|c|c|}
\hline \multirow{2}{*}{$\begin{array}{c}\text { Підприємство, } \\
\text { де проводили } \\
\text { дослідження } \\
\text { з визначення } \\
\text { фактичних } \\
\text { втрат спирту }\end{array}$} & \multirow[b]{2}{*}{$\begin{array}{l}\text { № } \\
\text { дос- } \\
\text { ліду }\end{array}$} & \multicolumn{2}{|c|}{$\begin{array}{l}\text { Кількість } \\
\text { безводного } \\
\text { спирту, дал }\end{array}$} & \multicolumn{4}{|c|}{$\begin{array}{c}\text { Фактичні втрати, дал безводного } \\
\text { спирту }\end{array}$} & \multicolumn{2}{|c|}{ Загальні втрати } \\
\hline & & \begin{tabular}{|c} 
пода- \\
ного на \\
уста- \\
новку
\end{tabular} & $\begin{array}{c}\text { отри- } \\
\text { маного } 3 \\
\text { про- } \\
\text { дуктами }\end{array}$ & $\begin{array}{c}3 \text { бар- } \\
\text { дою }\end{array}$ & $\begin{array}{c}3 \text { лю- } \\
\text { тер- } \\
\text { ною } \\
\text { водою }\end{array}$ & $\begin{array}{l}3 \text { га- } \\
\text { зами }\end{array}$ & 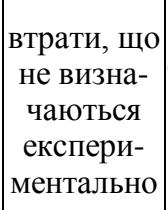 & $\begin{array}{c}\text { дал без- } \\
\text { вод- } \\
\text { ного } \\
\text { спирту }\end{array}$ & $\begin{array}{c}\text { \% від } \\
\text { спирту } \\
\text { поданого } \\
\text { на уста- } \\
\text { новку }\end{array}$ \\
\hline 1 & 2 & 3 & 4 & 5 & 6 & 7 & 8 & 9 & 10 \\
\hline ДП «Наумівсь- & 1 & 4886,7 & 4755,6 & 9,0 & 0,2 & 0,9 & 121,0 & 131,1 & 2,68 \\
\hline кий спирт & 2 & 2686,5 & 2611,8 & 4,6 & 0,1 & 1, & 68 & 74,7 & 2,78 \\
\hline завод» & 3 & 2737,6 & 2664,8 & 4,8 & 0,1 & 1,4 & 66,5 & 72,8 & 2,66 \\
\hline
\end{tabular}

Таблиия 2. Фактичні втрати спирту етилового під час виробництва зневодненої спиртовмісної продукції з бражки в осінньо-зимовий період 


\begin{tabular}{|c|c|c|c|c|c|c|c|c|c|}
\hline \multicolumn{1}{|c|}{ Пр } & 2 & 3 & 4 & 5 & 6 & 7 & 8 & 9 & 10 \\
\hline \multirow{2}{*}{ ДП «Гайсинсь- } & 1 & 6157,8 & 6050,2 & 11,9 & 0,02 & 1,9 & 93,8 & 107,6 & 1,75 \\
кий спиртовий & 2 & 6632,5 & 6527,7 & 12,4 & 0,03 & 2,2 & 90,2 & 104,8 & 1,58 \\
завод» & 3 & 6714,2 & 6600,1 & 33,9 & 0,06 & 2,2 & 77,9 & 114,3 & 1,70 \\
& 4 & - & - & - & - & - & - & - & - \\
\hline & 1 & 1955,9 & 1924,4 & 2,3 & 4,8 & 0,9 & 23,6 & 31,6 & 1,62 \\
ТОВ «БІОПЕК» & 2 & 4629,1 & 4551,7 & 1,8 & 10,4 & 0,5 & 64,7 & 77,4 & 167 \\
& 3 & 5147,5 & 5059,0 & 0,9 & 13,1 & 0,6 & 73,9 & 88,5 & 1,72 \\
& 4 & 4321,1 & 4246,8 & 0,7 & 8,1 & 0,7 & 64,7 & 74,3 & 1,72 \\
\hline
\end{tabular}

Експериментальні дослідження фактичних втрат спирту етилового під час виробництва зневоднених спиртовмісних рідин з бражки із застосуванням адсорбції на молекулярних ситах на ТОВ «Біопаливно-енергетична компанія» підтвердили попередньо отримані результати на ДП «Гайсинський спиртовий завод. Середні фактичні втрати спирту в осінньо-зимовий період року на ТОВ «Біопаливноенергетична компанія» склали:

$$
\mathrm{B}_{\text {cep. }}=(31,6+77,4+88,5+74,3) \cdot 100 /(1955,9+4629,1+5147,5+4321,1)=1,69 \% .
$$

На основі результатів проведених експериментальних досліджень з визначення фактичних втрат спирту етилового встановлено такі нормативи втрат під час виробництва зневодненої спиртовмісної продукції з бражки, у \% від безводного спирту поданого на установку під час застосування зневоднення:

- азеотропною ректифікацією з циклогексаном у весняно-літній період року у розмірі $3,0 \%$, в осінньо-зимовий період року $-2,8 \%$;

- мембранною первапорацією у весняно-літній період року у розмірі $-2,9 \%$, в осінньо-зимовий період року - 2,7\%;

- адсорбцією на молекулярних ситах у весняно-літній період виробництва у розмірі $1,9 \%$, в осінньо-зимовий період року - $1,7 \%$ від безводного спирту поданого на установку.

Результати проведених вибіркових досліджень фактичних втрат спирту етилового на безперервно діючих брагоректифікаційних установках підтвердили актуальність нормативів втрат, передбачених попередньою редакцією «Нормативів гранично допустимих втрат спирту на безперервно діючих брагоректифікаційних установках», під час виробництва 3 бражки спирту етилового ректифікованого різних сортів, спирту етилового технічного марок А, Б і В та флегмового компонента ректифікації денатурованого.

Висновки. У результаті проведених досліджень вперше експериментально визначено фактичні втрати спирту етилового під час виробництва зневодненої спиртовмісної продукції з бражки із застосуванням зневоднення адсорбцією на молекулярних ситах і зневоднення первапорацією на напівпроникливих мембранах, а також уточнено фактичні втрати спирту етилового під час виробництва зневодненої спиртовмісної продукції з бражки із застосуванням зневоднення азеотропною ректифікацією з циклогексаном.

\section{ЛIТЕРАТУРА}

1. Виробництво етилового спирту з харчової сировини. Терміни та визначення: ДСТУ 3296-95. — К.: Київ, Держстандарт, 1996. — 38 с. —(Національний стандарт України).

2. Брей В. В. Біоетанол в Україні / В. В. Брей, І. В. Щуцький // Вісник Національної Академії наук України. — 2016. —№ 6. - С. 71-76.

3. Золотарьова О. Куди прямує біопаливна індустрія / О. Золотарьова, Є. Шнюкова // Вісник Національної Академії наук України. — 2010. — № 4. — С. 10-20. 
4. Калетник Г. М. Перспективи виробництва біоетанолу в Україні / Г. М. Калетник // Вісник аграрної науки. — 2008. — № 11. - С. 45-50.

5. Розроблення та випробування технології комплексного трансформування вуглеводного складу рослинної сировини у біоетанол / С. П. Циганков, О. І. Володько, А. І. Ємець та інш. // Наука та інновації. — 2013. - № 4. - С. 55-69.

6. Методика визначення втрат спирту на безперервнодіючих брагоректифікаційних установках, в т.ч., енерго- та ресурсозберігаючих. - Київ: ДНУ «УкрНДІспиртбіопрод», 2016. $-27 \mathrm{c}$.

\title{
РАЗРАБОТКА НОРМАТИВОВ ГРАНИЧНО- ДОПУСТИМЫХ ПОТЕРЬ СПИРТА ЭТИЛОВОГО ПРИ ПРОИЗВОДСТВЕ ОБЕЗВОЖЕННОЙ СПИРТОСОДЕРЖАЩЕЙ ПРОДУКЦИИ ИЗ БРАЖКИ
}

\author{
Г. А. Кизюн, А. С. Мищенко, А. А. Можаровская \\ ГНУ «УкрНИИспиртбиопрод» \\ С. И. Олейник \\ Национальный университет пищевых технологий
}

Проанализировано существующие нормативы предельно допустимых потерь спирта этилового при производстве спиртосодержащих продуктов из бражки и разработано методику определения фрактических потерь спирта при производстве биоэтанола, фрлегмового компонента ректификации обезвоженного (ФКРЗ) и спирта этилового ректифицированного абсолютированного (СЕРА) методом адсорбции на полупроницаемых мембранах и азеотропной ректифиикацией. Экспериментальным путем определены фрактические потери спирта в производстве обезвоженной спиртосодержащей продукции при применении различных способов обезвоживания. Обобщены полученные результаты исследований и разработан проект нормативов предельно допустимых потерь спирта при производстве спиртосодержащей продукции с созревшей бражки.

Ключевые слова: предельно допустимые нормы потерь, спирт этиловый ректифицированный, спиртосодержащая продукция, обезвоживание, адсорбция, полупроницаемые мембраны, азеотропная ректияикация, объем безводного спирта. 